\title{
Association of IVS6A GATT polymorphism of CFTR gene with cystic fibrosis: first study in CF and normal Tunisian population
}

\author{
Association du polymorphisme IVS6A GATT du gène CFTR : \\ première étude dans une population tunisienne mucoviscidosique
}

\author{
Sahli Chaima ${ }^{1}$ \\ Hadj Fredj Sondess ${ }^{1}$ \\ Boussetta Khedija ${ }^{2}$ \\ Mehrezi Ahmed ${ }^{3}$ \\ Messaoud Taieb ${ }^{1}$ \\ ${ }^{1}$ Biochemistry laboratory, \\ Children's hospital Bechir Hamza, \\ Research laboratory LR00SP03, \\ Tunis, Tunisia \\ ${ }^{2}$ Department of pediatrics, \\ Children's hospital Bechir Hamza, \\ Tunis, Tunisia \\ ${ }^{3}$ Department of pediatrics, \\ Hospital Mongi Slim, Tunis, Tunisia
}

\begin{abstract}
Background: Cystic fibrosis (CF) is the most common autosomal recessive disease in Caucasians, caused by mutation in cystic fibrosis transmembrane conductance regulator (CFTR). The analysis of some extra and intragenic markers within or closely linked to CFTR gene is useful as a molecular method in clinical linkage analysis. Indeed, knowing that the molecular basis of CF is highly heterogeneous in our population is explained in the present study. In this work, we are interested for the first time to study the polymorphic marker IVS6a GATT in a CF Tunisian population. Methods: Our study involved $80 \mathrm{CF}$ Tunisian patients with a positive sweat test. A cohort of 90 healthy controls was also enrolled. The analysis of the variant IVS6a GATT was conducted by analysis of the fragments on automatic sequencer (ABI Prism 310). A statistical analysis was performed on Statistical Package for the Social Sciences (SPSS) version 20 software. Results: The analysis of genotypic distribution of IVS6aGATT showed a significant difference between the control and $\mathrm{CF}$ groups suggesting the involvement of this marker in cystic fibrosis. Furthermore, we noted that the 6 GATT repetition in the homozygous state is more common in CF patients than in the control group $(\mathrm{p}<0.05)$. This while the 7GATT/7GATT genotype is more common among controls compared to CF patients $(\mathrm{p}=0.002)$. Regarding the interest of this polymorphism on the clinical expression of cystic fibrosis, we have noted no significant association between 6/6 genotype with different clinical conditions in CF patients outside the CFTR mutation. While a significant association was found between respiratory involvement and mixed (respiratory and digestive) and the 6/6 genotype in patients with the mutation F508del homozygous $(\mathrm{p}<0.05)$. In addition, a significant association was also noted with gastrointestinal involvement for non F508del patients/F508del not $(\mathrm{p}=0.014)$. Given that, phenotypic and genotypic heterogeneity of cystic fibrosis, several studies have sought to highlight the role of genetic markers linked to the CFTR gene in the expression and evolution of the disease. Conclusion: Our study on the implication of polymorphic marker IVS6a GATT is one of the first works carried out in the Tunisian population and confirms the usefulness of this marker in the clinical expression of cystic fibrosis.
\end{abstract}

Key words: CFTR gene, IVS6A GATT marker, Tunisian population, phenotypic variability, F508del mutation

Résumé. Depuis la description du gène CFTR, plus de 2000 mutations ont été rapportées à travers le monde documentant l'extrême variabilité génotypique et phénotypique de la pathologie. L'étude des corrélations phénotype-génotype s'avère essentielle dans cette maladie multifactorielle afin de mieux comprendre 
son expression clinique. Dans ce travail, nous nous sommes intéressés à étudier la répartition génotypique et allélique du polymorphisme IVS6aGATT dans une population tunisienne ainsi que d'établir son implication chez les patients mucoviscidosiques en association avec la mutation la plus commune F508del. Patients et méthodes : Notre étude a porté sur 80 enfants mucoviscidosiques et 90 sujets sains. L'étude du variant IVS6aGATT a été réalisée par l'analyse des fragments sur séquenceur automatique (ABI Prism 310). L'étude statistique a été menée par le logiciel SPSS (version 20.0). Résultats et discussion: L'analyse de la distribution génotypique du marqueur intragénique IVS6aGATT a montré une différence significative entre le groupe de contrôle et le groupe des patients, ce qui suggère l'implication de ce marqueur dans la mucoviscidose. Par ailleurs, nous avons noté que la répétition 6 GATT à l'état homozygote est plus fréquente chez les patients CF que chez le groupe des témoins avec $\mathrm{p}$ $<0,05$. Cependant, la forme heptamètre (7GATT/7GATT) est plus commune chez les témoins par rapport aux patients $\mathrm{CF}(\mathrm{p}=0,002)$. En ce qui concerne l'intérêt de ce polymorphisme sur l'expression clinique de la mucoviscidose, nous n'avons noté aucune association significative entre le génotype 6/6 avec les différentes atteintes cliniques chez les patients mucoviscidosiques en dehors de la mutation CFTR. En revanche, une association significative a été montrée entre l'atteinte respiratoire et l'atteinte mixte (respiratoire et digestive) et le génotype 6/6 chez les patients porteurs de la mutation F508del à l'état homozygote $(\mathrm{p}<0,05)$. De plus, une association significative a été également notée avec l'atteinte digestive pour les patients non F508del/non F508del ( $\mathrm{p}=0,014)$. Conclusion: Etant donné l'hétérogénéité phénotypique et génotypique de la mucoviscidose, plusieurs études ont cherché à mettre en évidence le rôle des marqueurs génétiques liés au gène CFTR dans l'expression et l'évolution de la maladie. Notre travail, portant sur l'intérêt du polymorphisme IVS6aGATT du gène $C F T R$, constitue l'un des premiers travaux effectués dans la population tunisienne et confirme l'utilité de ce marqueur dans l'expression clinique de la mucoviscidose.

Mots clés : gène CFTR, marqueur IVS6A GATT, population tunisienne, variabilité phénotypique, mutation F508del

Cystic fibrosis (CF) (OMIM number: 219700) is the most common severe autosomal recessive disease in Caucasians. It affects about one of 2000-3000 newborns and approximately one in 25 individuals is heterozygote. Indeed, the gold standard for the diagnosis of $\mathrm{CF}$ is the sweat test [1] and caused by mutation in cystic fibrosis transmembrane conductance regulator (CFTR). The CFTR gene had been identified two decades ago. It was located on the long arm of chromosome 7 (7q31 locus, 27 exons), codes for CFTR protein operating as a chloride channel that regulates salt and water transport across epithelial cell membranes [2-4]. In accordance to disease severity and age of diagnosis (from the first year of life to the third decade or later) the clinical manifestations differ greatly. Currently, over than 2000 sequence variations have been described within the CFTR gene, along with geographic and ethnic variations in their distribution and frequency [5]. These variations confer somewhat variable phenotypes from classic $\mathrm{CF}$ to atypical $\mathrm{CF}$ with less severe pulmonary lesions, pancreatic sufficiency, and normal or borderline sweat chloride concentration [6, 7]. Additional effects of genetic factors (genetic markers and modifier genes) and/or environmental factors may cause clinical heterogeneity of CF. Thereby CF seems to be very common in Tunisia. Few CFTR mutation detection studies have been done in our country [8] and there has been very little research on modifier genes and polymorphisms. To facilitate finding polymorphisms that could be used as markers for prefertilization, pre-implantation and prenatal diagnosis and to provide better genetic counseling for family and patients with $\mathrm{CF}$, the following polymorphism were investigated:

A short tandem repeated polymorphism IVS6AGATT c.744-33GATT (rs1805176; chromosome 7:117536517_ 117536520) was identified at the junction of intron IVS6A and exon 6B as described previously by Gaspirin et al. [9]. Moreover, which can have six or seven repeated sequences and it was the subject of several studies in CF and healthy cohorts [10]. Furthermore, Chehab et al. and Dork et al. 
Table 1. Allelic and genotypic distribution of IVS6a GATT polymorphism in our cohort.

\begin{tabular}{|llllll|}
\hline IVS6A GATT marker & $\begin{array}{l}\text { CF Patients } \\
\%\end{array}$ & $\begin{array}{l}\text { Controls group } \\
\%\end{array}$ & ORs & CI95\% & p \\
\hline $6 / 6$ & 50 & 16.66 & 5 & $2.46-10.13$ & $\mathbf{0 . 0 0 0 1}$ \\
\hline $6 / 7$ & 16.25 & 23.33 & 0.63 & $0.29-1.37$ & 0.25 \\
\hline $7 / 7$ & 33.75 & 56.66 & 0.39 & $0.20-0.72$ & 0.002 \\
\hline $7 / 8$ & - & 3.33 & - & $2.23-5.51$ & 0.0001 \\
\hline 6 & 58.12 & 28.33 & 3.5 & $0.19-0.48$ & $\mathbf{0 . 0 0 0 1}$ \\
\hline 7 & 41.87 & 70 & 3.20 & $0.13-74.82$ & 0.46 \\
\hline 8 & - & 1.66 & & & 0.32 \\
\hline
\end{tabular}

In bold significant value $p<0.05$

noted complete association between the 6 repeat allele of IVS6 AGATT and the most common disease-causing mutation, F508del (c.1521_1523delCTT), seems to be very common in Tunisia and is found in $70 \%$ of Caucasian CF patients whereas the frequency of other common mutations does not exceed 3\% [11-13]. Few CFTR mutation detection studies have been done in our country [8], and there has been very little research on polymorphisms. In this study we were interested for the first time to study the implication of polymorphic marker IVS6A GATT in the clinical expression of CF patients.

\section{Patients and methods}

Our study involved $80 \mathrm{CF}$ Tunisian patients aged between three months and 17 years with an average of $28 \pm$ 3.5 months. Diagnosis of CF was determined in patients through two doses of sodium and chloride from sweat with values $>60 \mathrm{mEq} / \mathrm{L}(97,5 \pm 42,5 \mathrm{mmol} / \mathrm{L})$ using the pilocarpine iontophoresis test. $40 \%$ of these patients are from consanguineous marriage. A cohort of 90 healthy controls was enrolled in the study with no family history of CF.

All parents of our patients signed informed consents. This work was carried out in accordance with the Ethical guidelines of the World medical association declaration of Helsinki.

CFTR mutations were previously identified using denaturing high performance liquid chromatography (DHPLC), denaturing gradient gel electrophoresis (DGGE) and direct sequencing [14-16]. Different CFTR genotypes were determined in 80 analyzed patients: 65 patients $(81.25 \%)$ with homozygous mutations (60\% F508del/F508del, 18.75\% $\mathrm{E} 1104 \mathrm{X} / \mathrm{E} 1104 \mathrm{X}$ and $2.5 \% 711+1 \mathrm{G} \rightarrow \mathrm{T} / 711+1 \mathrm{G} \rightarrow \mathrm{T})$, 6 patients $(7.5 \%)$ with double heterozygous mutations (5\% F508del/G542X and 2.5\% F508del/ N1303K) and 9 patients $(11.25 \%)$ with one identified mutation $(8.75 \%$ F508del/ undetermined and 2.5\% E1104X/undetermined). Polymorphism IVS6A GATT were studied by direct sequencing on ABI prism 310 (Applied biosystemes,
California, USA) and was used to analyze the junction of intron 6A/exon 6B. Genomic DNA was amplified by primers spanning the splicing acceptor site of exon 6B [12]. PCR products were purified with the kit Wizard SV Gel and PCR clean up system (Promega, Madison, WI) and were sequenced using the Big dye terminator cycle sequencing reaction kit (PE Applied BioSystem, Foster City, California, USA). Each single stranded product was concentrated using a centri-sep column (Applied Bio systems, Foster City, California, USA).

Statistical analysis was performed on Statistical package for the social sciences (SPSS) version 20 software. Differences between the means of the 2 continuous variables were evaluated by student test. Odds ratio (OR) and $95 \%$ confidence intervals $(95 \% \mathrm{CI})$ were calculated as strength of association between alleles or genotypes and CF patients. A p value of 0.05 was considered statistically significant.

\section{Results and discussion}

The table 1 shows the genotypic and allelic distribution of IVS6a GATT polymorphism in CF patients as well as in the control group. A significant difference was noted between our two groups analyzed (table 1 ).

Furthermore, we noted that the 6 GATT repetition in the homozygous state is more common in $\mathrm{CF}$ patients than in the control group ( $50 \%$ vs $16.70 \%$ ) with $\mathrm{p}<0.05$, OR $=5.95 \% \mathrm{Cl}=[2.46-10.13]$. A dominance of the genotype heptameter (GATT 7/ GATT 7) in controls versus CF patients was observed (56.7\% vs $33.8 \%$ ) with a significant difference

$\mathrm{p}=0.002, \mathrm{OR}=0.39,95 \% 0.20-0.72]$ (table 1$)$.

As for allelic distribution, we found a significant difference between the control group and the patients group ( $\mathrm{p}<<<$ $0.05)$ with a predominance of the GATT 6 in the patients compared to the controls ( $58.13 \%$ vs $28.33 \%$ ). It should be noted that the GATT 8 is only found in the healthy group with $1.66 \%$.

A statistical study was conducted to investigate possible involvement of IVS6a GATT polymorphism in the 
Table 2. Involvement of the genotypes of IVS6a GATT polymorphism in the variability of the clinical expression of CF patients.

\begin{tabular}{|c|c|c|c|c|c|c|c|c|c|c|c|c|c|}
\hline \multirow{3}{*}{$\begin{array}{l}\text { CF } \\
\text { mutations } \\
\\
\text { Homozygous } \\
\text { F508del } \\
N=37\end{array}$} & \multirow[t]{2}{*}{$\begin{array}{l}\text { IVS6aGATT } \\
\text { Variant }\end{array}$} & \multicolumn{4}{|c|}{ Respiratory disease } & \multicolumn{4}{|c|}{$\begin{array}{l}\text { Digestive } \\
\text { disease }\end{array}$} & \multicolumn{4}{|c|}{$\begin{array}{l}\text { Mixed disease } \\
\text { (respiratory } \\
\text { and digestive) }\end{array}$} \\
\hline & & $\begin{array}{l}\mathrm{P}^{*} \\
\%\end{array}$ & $\begin{array}{l}A \\
\%\end{array}$ & $\mathrm{p}$ & $\begin{array}{l}\text { OR } \\
\text { Cl 95\% }\end{array}$ & $\begin{array}{l}\mathrm{P}^{*} \\
\%\end{array}$ & $\begin{array}{l}\mathrm{A} \\
\%\end{array}$ & $\mathrm{p}$ & $\begin{array}{l}\text { OR } \\
\mathrm{Cl} \\
95 \%\end{array}$ & $\begin{array}{l}\mathrm{P}^{*} \\
\%\end{array}$ & $\begin{array}{l}\mathrm{A} \\
\%\end{array}$ & $\mathrm{p}$ & $\begin{array}{l}\text { OR } \\
\mathrm{Cl} \\
95 \%\end{array}$ \\
\hline & $6 / 6$ & 56.76 & 43.24 & 0.002 & $\begin{array}{l}4.75 \\
1.71-13.16\end{array}$ & 45.95 & 54.05 & 0.09 & $\begin{array}{l}2.29 \\
0.86-6.06\end{array}$ & 43.24 & 56.76 & 0.023 & $\begin{array}{l}3.26 \\
1.14-9.31\end{array}$ \\
\hline & Other & 21,62 & 78.38 & & & 27.03 & 72.97 & & & 18.92 & 81.08 & & \\
\hline \multirow{2}{*}{$\begin{array}{l}\text { No homozygous } \\
\text { F508del } \\
\mathrm{N}=43\end{array}$} & $6 / 6$ & 30.23 & 69.77 & 0.49 & $\begin{array}{l}0.73 \\
0.29-1.79\end{array}$ & 9.30 & 90.70 & 0.014 & $\begin{array}{l}0.23 \\
0.07-0.79\end{array}$ & 6.98 & 93.02 & 0.29 & $\begin{array}{l}0.46 \\
0.10-1.98\end{array}$ \\
\hline & Other & 37.21 & 62.79 & & & 30.23 & 69.77 & & & 13.95 & 86.05 & & \\
\hline \multirow{2}{*}{$\begin{array}{l}\text { Total } \\
\mathrm{N}=80\end{array}$} & $6 / 6$ & 42.50 & 57.50 & 0.1 & $\begin{array}{l}1.72 \\
0.89-3.31\end{array}$ & 26.25 & 73.75 & 0.72 & $\begin{array}{l}0.88 \\
0.44-1.76\end{array}$ & 23.75 & 76.25 & 0.23 & $\begin{array}{l}1.6 \\
0.73-3.52\end{array}$ \\
\hline & Other & 30 & 70 & & & 28.75 & 71.25 & & & 16.25 & 83.75 & & \\
\hline
\end{tabular}

$P^{*}$ : percentage presence, A: percentage absence, in bold: significant value $p<0.05$.

Table 3. Distribution of allelic percentages of IVS6a GATT polymorphism in our study and different populations.

\begin{tabular}{|lllllllc|}
\hline & $\begin{array}{l}\text { IVS6a GATT } \\
\text { polymorphism }\end{array}$ & Our study & Iran & Turkey & Brazil & Germany & Serbia \\
\hline Controls group & Allele 6 (\%) & 28,33 & 19,8 & - & 33,9 & 15 & 24 \\
\hline \multirow{2}{*}{$\begin{array}{l}\text { F508del } \\
\text { mutation }\end{array}$} & Allele 7(\%) & 70 & 80,2 & - & 66,1 & 84 & 76 \\
\hline $\begin{array}{l}\text { NoF508del } \\
\text { mutation }\end{array}$ & Allele 6(\%) & 73,61 & 84,2 & 89 & 70,83 & 100 & 96 \\
\cline { 2 - 8 } & Allele 7(\%) & 26,39 & 15,8 & 11 & 29,17 & 0 & 4 \\
\hline
\end{tabular}

variability of clinical expression of $\mathrm{CF}$ patients. No significant association was found between the 6/6 genotype and the different clinical expression in CF patients outside the CFTR mutations. However, a significant association was found between respiratory involvement and mixed (respiratory and digestive) involvement and 6/6 genotype in patients with homozygous F508del mutation ( $\mathrm{p}<0.05$ ). In addition, a significant association was also observed with gastrointestinal involvement for no F508del/ no F508del patients $(\mathrm{p}=0.014)$. The obtained results suggest that the IVS6a GATT polymorphism is involved in the variability of clinical expression of CF patients (table 2).

By comparing the allelic distribution of the IVS6a GATT polymorphism in association with the most frequent mutation in this pathology F508del; we found a significant association between GATT 6 and the F508del mutation (p $=0.04)$. This result is in agreement with those reported by Ôzuc et al. with $\mathrm{p}<0.001$ [17] and Dôrk et al. with $\mathrm{p}<0.001$ [12], but this result is in divergence with those found by Furgeri et al. with $\mathrm{p}=0103$ [10]. In addition, GATT 6 is the most frequent allele in CF patients with F508del mutation in the homozygous state $(92.43 \%)$. Whereas, the GATT7 is the most dominant in the CF patients not carriers of the F508del mutation with $83.72 \%$. These findings are consistent with those found in the Iranian, Turkish, Brazilian, German, and Serbian populations (table 3) [12, 18, 19].

According to our recognition, this work constitutes the first study which is interested in evaluating the role of this polymorphism on the variability of the clinical expression in CF patients. In fact, patients with F508del mutation in the homozygous state and 6/6 genotype hard more risk to develop respiratory disease or mixed disease (respiratory and digestive). From the results obtained in our study, it appears that IVS6a GATT polymorphism may be involved in the variability of clinical expression in CF patients.

\section{Conclusion}

In view of the phenotypic and genotypic heterogeneity of $\mathrm{CF}$, many studies have attempted to highlight the role of genetic markers linked to the CFTR gene in the expression and evolution of the disease. Our study concerning the 
impact of polymorphic marker IVS6a GA TT is one of the first works in Tunisian population and confirm the usefulness of this marker in the clinical expression of cystic fibrosis.

Acknowledgments. The authors wish to thank all CF patients of the Children's Hospital of Tunis. This work has been supported by the Ministry of Scientific Research and Technology and Competence Development (LR00SP03).

Conflict of interest: none of the authors has any conflict of interest to disclose concerning this article.

\section{References}

1. Farrell PM, White TB, Ren CL, Hempstead SE, Accurso F, Derichs $\mathrm{N}$, et al. Diagnosis of cystic fibrosis: consensus guidelines from the cystic fibrosis foundation. J Pediatr 2017 ; 181S : S4-15.

2. Farrell PM, White TB, Derichs N, Castellani C, Rosenstein BJ. Cystic fibrosis diagnostic challenges over 4 decades: historical perspectives and lessons learned. J Pediatr 2017; 181S : S16-26.

3. Sosnay PR, White TB, Farrell PM, Ren CL, Derichs N, Howenstine MS, et al. Diagnosis of cystic fibrosis in non screened populations. J Pediatr 2017 ; 181S : S52-7.

4. Rosenfeld M, Sontag MK, Ren CL, Sheller R, Edelman S, Yusuf C, et al. Cystic fibrosis diagnosis and newborn screening. Pediatr Clin North Am 2016;63(4) : 599-615.

5. Cystic fibrosis mutation database. http://www.genet.sickkids.on.ca/

6. Guillot L, Beucher J, Tabary O, Le Rouzic P, Clement A, Corvol H. Lung disease modifier genes in cystic fibrosis. Int J Biochem Cell Biol $2014 ; 52: 83-93$

7. Tabaripour R, Niaki HA, Douki MR, Bazzaz JT, Larijani B, Yaghmaei P. Poly thymidine polymorphism and cystic fibrosis in a non-Caucasian population. Dis Markers 2012;32:241-6.

8. Hadj Fredj S, Boudaya M, Oueslati S, Sahnoun S, Sahli C, Siala H, et al. New frameshift CF mutation 3729delAinsTCT in a Tunisian cystic fibrosis patient. J Genet 2013;92:81-3.
9. Gasparini P, Nunes V, Savoia A, Dognini M, Morral N, Gaona A, et al. The search for South European cystic fibrosis mutations: identification of two new mutations, four variants, and intronic sequences. Genomics $1991 ; 10: 193-200$.

10. Furgeri DT, Marson FAL, Correia CAA, Ribeiro JD, Bertuzzo CS. Cystic fibrosis transmembrane regulator haplotypes in households of patients with cystic fibrosis. Gene 2018;641: $137-43$.

11. Chehab FF, Johnson J, Louie E, Goossens M, Kawasaki E, Erlich $\mathrm{H}$. A dimorphic 4-pb repeat in the cystic fibrosis gene is in absolute linkage disequilibrium with the delta F508 mutation: implications for prenatal diagnosis and mutation origin. Am J Hum Genet 1991;48: 223-6.

12. Dörk T, Neumann T, Wulbrand U, Wulf B, Kälin N, Maass G, et al. Intra- and extragenic marker haplotypes of CFTR mutations in cystic fibrosis families. Hum Genet 1992; 88(4) : 417-25.

13. Ratkiewicz M, Pastore M, McCoy KS, Thompson R, Hayes Jr. D, Sheikh SI. Role of CFTR mutation analysis in the diagnostic algorithm for cystic fibrosis. World J Pediatr 2017; 13(2) : 129-35.

14. Messaoud T, Bel Haj Fredj S, Bibi A, Elion J, Férec C, Fattoum S. Molecular epidemiology of cystic fibrosis in Tunisia. Ann Biol Clin (Paris) $2005 ; 63: 627-30$

15. Fredj SH, Messaoud T, Templin C, Des Georges M, Fattoum S, Claustres M. Cystic fibrosis transmembrane conductance regulator mutation spectrum in patients with cystic fibrosis in Tunisia. Genet Test Mol Biomarkers 2009; 13 : 577-81.

16. Boudaya M, Fredj SH, Siala H, Bibi A, Messaoud T. Identification of a cystic fibrosis mutation W19X in Tunisia. Ann Biol Clin (Paris) $2013 ; 71: 223-6$

17. Ozgüç M, Yilmaz E, Erdem H, Coşkun T, Ozçelik U, Togan I, et al. Allele frequencies of Mp6D-9 and GATT markers in 32 Turkish cystic fibrosis families. Clin Genet $1994 ; 45: 266-8$.

18. Kholghi Oskooei V, Esmaeili Dooki MR, Tabaripour R, Mirzajani S, Pourbagher R, Akhavan-Niaki H. CFTR haplotypes in northern Iranian population. Gene $2013 ; 512(1)$ : 55-60.

19. Cabello GM, Cabello PH, Lopez-Camelo JS, Llerena Jr. JC, Fernandes O. Haplotype distribution of and linkage disequilibrium between four polymorphic markers near the CFTR locus in Brazilian cystic fibrosis patients. Hum Biol 2005 ; 77(6) : 853-65. 